Transactions of the American Fisheries Society, 2000, v.129, n.1, pp.1-12. http://afs.allenpress.com

http://afs.allenpress.com/archive/1548-8659/129/1/pdf/i1548-8659-129-1-1.pdf Online ISSN: 1548-8659

Print ISSN: 0002-8487

DOI: 10.1577/1548-8659(2000)129<0001:OGASOL>2.0.CO;2

(C) American Fisheries Society 


\title{
Overwinter Growth and Survival of Largemouth Bass: Interactions among Size, Food, Origin, and Winter Severity
}

\author{
Aimee H. Fullerton, ${ }^{1}$ James E. Garvey, ${ }^{* 2}$ Russell A. Wright, ${ }^{3}$ \\ AND Roy A. STEIN \\ Aquatic Ecology Laboratory, Department of Evolution, Ecology, and Organismal Biology, \\ The Ohio State University, Columbus, Ohio 43212-1156, USA
}

\begin{abstract}
Winter severity (temperature, duration, and photocycle), geographic origin, food availability, and initial body size likely influence growth, survival, and, therefore, recruitment of age0 largemouth bass Micropterus salmoides. We collected age-0 largemouth bass (70-160 mm total length) from low $\left(33^{\circ} \mathrm{N}\right)$, intermediate $\left(40^{\circ} \mathrm{N}\right)$, and high $\left(45^{\circ} \mathrm{N}\right)$ latitudes throughout their natural range (origin), and we subjected all three groups of fish to three experimental winters that mimicked these latitudes ( $N=9$ largemouth bass per treatment). Within each winter and origin, one-half of the largemouth bass were fed fish prey, whereas the remaining one-half were starved. Winter strongly influenced survival; overall survival rates in the high-, intermediate-, and low-latitude winters were $34.9,59.4$, and $61.1 \%$, respectively ( $\chi^{2}$ test, $\left.P<0.05\right)$. Largemouth bass from $33^{\circ} \mathrm{N}$ suffered high mortality in the high-latitude winter. Across all winters, more fed fish $(64.5 \%)$ survived than did starved fish $(38.1 \%)\left(\chi^{2}\right.$ test, $\left.P<0.05\right)$. Pooling fish into small $(<100 \mathrm{~mm})$ and large $(\geq 100 \mathrm{~mm})$ size classes revealed that more small fish died than did large fish in the low- and high-latitude winters, but this was not the case in the middle-latitude winter. Wet weights (g) of fed largemouth bass increased, remained constant, and declined in the low-, intermediate-, and high-latitude winters, respectively. Wet weights and total energy content $(\mathrm{kJ})$ of fed individuals were consistently higher than those of their starved counterparts in all winters. However, energy density $(\mathrm{kJ} / \mathrm{g})$ of fed individuals often declined to levels similar to those of starved largemouth bass. Winter temperature combined with duration likely dictate the northern limit of largemouth bass by reducing growth, even when food is abundant. Because survival of individuals from the low latitude was poor in higher latitude winters, stocking southern largemouth bass in northern systems may translate to high mortality and perhaps to degradation of physiological tolerances of local populations through hybridization.
\end{abstract}

Overwinter survival during the first year of life may drive the recruitment and, thus, the yearclass strength of many fishes (Oliver et al. 1979; Toneys and Coble 1979; Post and Evans 1989). Poor first-summer growth resulting in small fall body size is often implicated as a primary factor influencing winter survival (Gutreuter and Anderson 1985). In addition, winter survival may be influenced by local factors, including food availability and local adaptation, and geographic processes, such as winter severity (defined as duration, photoperiod, and temperature regime). In order to understand what factors govern variability in first-winter survival across the range of

\footnotetext{
* Corresponding author: jgarvey@ksu.edu

${ }^{1}$ Present address: North Carolina Wildlife Resources Commission, 102 West Whitaker Mill Road, Raleigh, North Carolina 27608, USA.

2 Division of Biology, Kansas State University, Manhattan, Kansas 66506, USA.

${ }^{3}$ Department of Fisheries and Allied Aquacultures, Auburn University, Auburn, Alabama 36849, USA.
}

Received September 16, 1998; accepted March 2, 1999 a species, we must determine the relative importance and the potential interactions of these factors. Herein, we explore how these factors influence the first-winter growth and survival of largemouth bass Micropterus salmoides, a widely sought sport fish (Hall 1996).

For age-0 largemouth bass, size-selective mortality should be greatest at the highest latitudes, where winters are most severe (Post and Evans 1989; Schultz and Conover 1997). This expectation is based on several assumptions, including cessation of feeding (Johnson and Charlton 1960; Coutant 1975; Oliver et al. 1979; Miranda and Hubbard 1994a, 1994b), during which energy for metabolic needs is provided by body stores (Sullivan 1986). Owing to their higher weight-specific metabolic rates (Brett and Groves 1979; Rice et al. 1983; Jobling 1993), small fish may be more susceptible to starvation than large fish (Oliver et al. 1979; Sullivan 1986; Smith and Griffith 1994; Griffiths and Kirkwood 1995; Cargnelli and Gross 1996, 1997; Meyer and Griffith 1997). Hence, exhaustion of energy reserves is often implicated as 
the primary mechanism underlying size-dependent overwinter mortality.

The exact mechanism by which small size influences overwinter survival of largemouth bass may be less certain than it was once thought. A literature review revealed a counterintuitive pattern: small largemouth bass suffer higher mortality than do their larger counterparts at low latitudes, but mortality depends less on size as latitude increases (Garvey et al. 1998). Although the degree of winter severity across the range of largemouth bass may influence survival (Conover 1990; Lyons 1997), environmental effects may change with initial body size and food availability. During winter, food may be scarce, causing largemouth bass to deplete their energy reserves, perhaps compromising immune defenses. Thus, susceptibility of age-0 largemouth bass to predation, disease, and starvation may increase (Sullivan 1986; Adams and DeAngelis 1987). Even so, this species may contend with severe winter conditions by entering a torporlike state at temperatures generally thought to be less than $10^{\circ} \mathrm{C}$ (Johnson and Charlton 1960; Crawshaw 1984). All of these flexible mechanisms may create size-specific overwinter mortality variability among systems within the same latitude (Garvey et al. 1998).

Differential winter survival across the range of largemouth bass also may be influenced by adaptations of individual populations to local environmental conditions. Two subspecies of largemouth bass, northern M. s. salmoides and Florida M. s. floridanus, and their hybrids have been identified (Philipp et al. 1983; Brown and Murphy 1994; Gelwick et al. 1995; Whitmore and Craft 1996). Populations from different latitudes may have adapted differently in response to winter severities and may have genetically different thermal tolerances (Bennett et al. 1997). Thus, patterns of size-selective winter mortality may be driven by the interaction between phenotypic responses of locally adapted populations and their unique suite of environmental conditions.

Given the unresolved mechanisms underlying the success of age- 0 largemouth bass during winter, we conducted an experiment to determine how both local (i.e., origin, food availability, and initial size) and geographic (i.e., winter severity) factors influence the growth and survival of this species. Winters from low $\left(33^{\circ} \mathrm{N}\right)$, intermediate $\left(40^{\circ} \mathrm{N}\right)$, and high $\left(45^{\circ} \mathrm{N}\right)$ points along a latitudinal gradient were mimicked in three controlled-environment rooms. During each experimental winter, small and large age-0 largemouth bass collected from each latitude were either fed or starved. We hypothesized that the negative effects caused by reduced food, suppressed foraging activity, and increased starvation would increase with latitude and that the effect of winter would be most severe for small individuals. Further, we predicted that largemouth bass originating from low latitudes would suffer high mortality in cold, high-latitude winters.

\section{Methods}

During summer through fall of 1994, age-0 largemouth bass were collected (by shoreline seining or pulsed DC electrofishing) from (1) ponds on the campus of Auburn University (Alabama; 333' $34^{\prime \prime} \mathrm{N}$ ), (2) Knox Lake (central Ohio; $40^{\circ} 42^{\prime} 50^{\prime \prime} \mathrm{N}$ ), and (3) Trilby Lake (northern Wisconsin; 45 $52^{\prime} 17^{\prime \prime} \mathrm{N}$ ). Before the experiments began, largemouth bass stocks (i.e., fish with different geographic origins) were held separately for 6 weeks in tanks with flow-through decholorinated city water $\left(15-20^{\circ} \mathrm{C}\right)$ and were fed fathead minnows Pimephales promelas.

In order to simulate winter conditions similar to those at southern, middle, and northern points within the range of largemouth bass, we controlled temperature and incandescent light in three experimental rooms at the Aquatic Ecology Laboratory at The Ohio State University. Temperature and photoperiods mimicked those from Alabama, Ohio, and Wisconsin winters. Temperatures were adjusted daily based on winter temperature profiles for (1) ponds on the campus of Auburn University (Ludsin 1994), (2) central Ohio reservoirs (Garvey et al. 1998), and (3) northern Wisconsin lakes (Long Term Ecological Research-North Temperate Lakes, 1992-1994). Each experimental winter began and ended at $15^{\circ} \mathrm{C}$. On a weekly basis we adjusted daylight hours to those found near the latitude from which the largemouth bass had been collected. Room temperatures were quantified several times daily during experimental winters with HoboTemp dataloggers (one per room).

Individual largemouth bass were marked with a combination of a latex dye injection in the caudal peduncle and a dorsal spine clip. Within each room (representing Alabama, Ohio, Wisconsin winters, respectively), largemouth bass were held in $55-\mathrm{L}$ aquaria that had been divided into three compartments; each compartment contained one treatment (three aquaria per treatment; three fish per compartment; $\mathrm{N}=9$ fish per treatment within each winter; total of 14 aquaria per winter). Each treatment combination consisted of a largemouth bass origin (Alabama, Ohio, or Wisconsin), a size class (see Table 1), and a feeding regime (fed or 
TABLE 1.- Initial total lengths $(\mathrm{mm})$ and wet weights (g) of age- 0 largemouth bass $(N=57$ largemouth bass per size-class), measured at the beginning of the 30-d acclimation period. Individuals were grouped into small, large, or extra-large size-classes for assignment to aquaria. Mean energy density $(\mathrm{kJ} / \mathrm{g})$ of a sample of largemouth bass $(N=18$ total $)$ was quantified at the outset of the experiment. An ANCOVA incorporating the effects of origin and length revealed that initial energy density was unrelated to length $(P=0.55)$ but differed among origins $(P=0.01)$.

\begin{tabular}{llrrr}
\hline \multirow{2}{*}{ Origin } & Size-class & $\begin{array}{c}\text { Length } \\
( \pm 1 \mathrm{SD})\end{array}$ & $\begin{array}{c}\text { Weight } \\
( \pm 1 \mathrm{SD})\end{array}$ & $\begin{array}{c}\mathrm{kJ} / \mathrm{g} \\
( \pm 1 \mathrm{SD})\end{array}$ \\
\hline Alabama & Small & $70(3)$ & $4.4(0.7)$ & $4.5(0.3)$ \\
& Large & $132(4)$ & $26.5(0.5)$ & \\
\multirow{2}{*}{ Ohio } & Small & $67(4)$ & $3.8(0.5)$ & $5.1(0.3)$ \\
& Large & $110(2)$ & $16.3(1.1)$ & \\
\multirow{4}{*}{ Wisconsin } & Extra-large & $161(4)$ & $51.8(3.6)$ & \\
& Small & $80(2)$ & $6.2(0.3)$ & $5.1(0.2)$ \\
& Large & $107(2)$ & $15.7(1.2)$ & \\
\hline
\end{tabular}

starved). Treatments were randomly assigned to compartments. For $30 \mathrm{~d}$ before the experiment, all largemouth bass were acclimated in these aquaria at $20^{\circ} \mathrm{C}$ while being fed a maintenance ration of prey fishes that was calculated using the Hewett and Johnson (1992) bioenergetics model.

Within each winter, fish from Alabama, Ohio, and Wisconsin were divided into two size classes, with the exception of Ohio fish, which also had an extra-large size class (Table 1). During the experiment, one-half of the largemouth bass in each size class were fed fish prey daily at a maintenance ration. Large and extra-large size classes were fed fathead minnows, whereas the small size class was fed guppies Poecilia reticulata. We recorded consumption by individual largemouth bass if prey were eaten within $10 \mathrm{~min}$. Prey that were not immediately consumed remained in aquaria for $24 \mathrm{~h}$. The following day, we removed uneaten prey and randomly assigned consumption of missing prey to largemouth bass. The second half of largemouth bass were starved during winter.

We determined consumption rates $\left(\mathrm{g} \cdot \mathrm{g}^{-1} \cdot\right.$ week $\left.^{-1}\right)$ by recording daily food intake of individual largemouth bass, as outlined above. Growth was quantified by measuring total length (to the nearest 1 $\mathrm{mm}$ ) and wet weight (to the nearest $0.1 \mathrm{~g}$ ) at the beginning of the experiment, at midwinter, and at the end of each winter. Growth rate $\left(\mathrm{g} \cdot \mathrm{g}^{-1} \cdot \mathrm{week}^{-1}\right)$ was calculated by taking the difference between the final and initial weights and by dividing this value by the number of weeks in a winter in order to standardize for comparisons across winters. En- ergy density (kJ/g wet weight) of largemouth bass was determined from individual fish using oxygen bomb calorimetry (per Rand et al. 1994). Energy density and total energy content were determined for a sample of largemouth bass from each origin and size at the beginning and end of the experiment. We quantified mortality by recording the time an individual died, to the nearest day. Aquaria were aerated, and water was both changed and monitored daily for ammonia levels.

Disease (ectoparasite Ichthyophthirius spp.) was apparently accidentally introduced into all tanks with prey fish on about day 120 of each winter, and some fish developed a secondary fungal infection (Saprolegnia spp.). In order to control the disease, we treated all aquaria equally with three consecutive doses (about 15 ppm; on days 121, 123 , and 125) of malachite green. Generally, infected individuals died. However, the treatment prevented transmission of the disease to relatively healthy individuals.

Statistical analyses.-We performed a Spearman's rank correlation test to assess whether consumption rates were related to temperature within each of the three winters. Although consumption of dying fish may be altered in advance of the date of death, we included consumption data of fish that died in our analysis. We used a threeway analysis of covariance (ANCOVA; SAS Institute) to analyze how size (the covariate, initial total length), origin, and the presence of food affected growth rates of individual largemouth bass in each experimental winter. We analyzed proportional change in energy density and total energy content in a manner similar to that used for growth rates. However, we included both dependent variables in a three-way multivariate analysis of variance (MANOVA), in which the effect of size was continuous and in which the effects of origin and food were categorical. Because determining initial energy content requires sacrificing of fish, we quantified initial values for individuals not used in experiments. Thus, proportional changes in energy density and energy content were calculated using origin-specific means at the start and individual measurements at the end (Table 1). Only significant interactions were included in the final model(s). Only data for fish remaining alive at the end of each experimental winter were used. We performed chi-square frequency tests to determine whether survival of largemouth bass to the end of each experimental winter depended on size, food presence, or geo- 


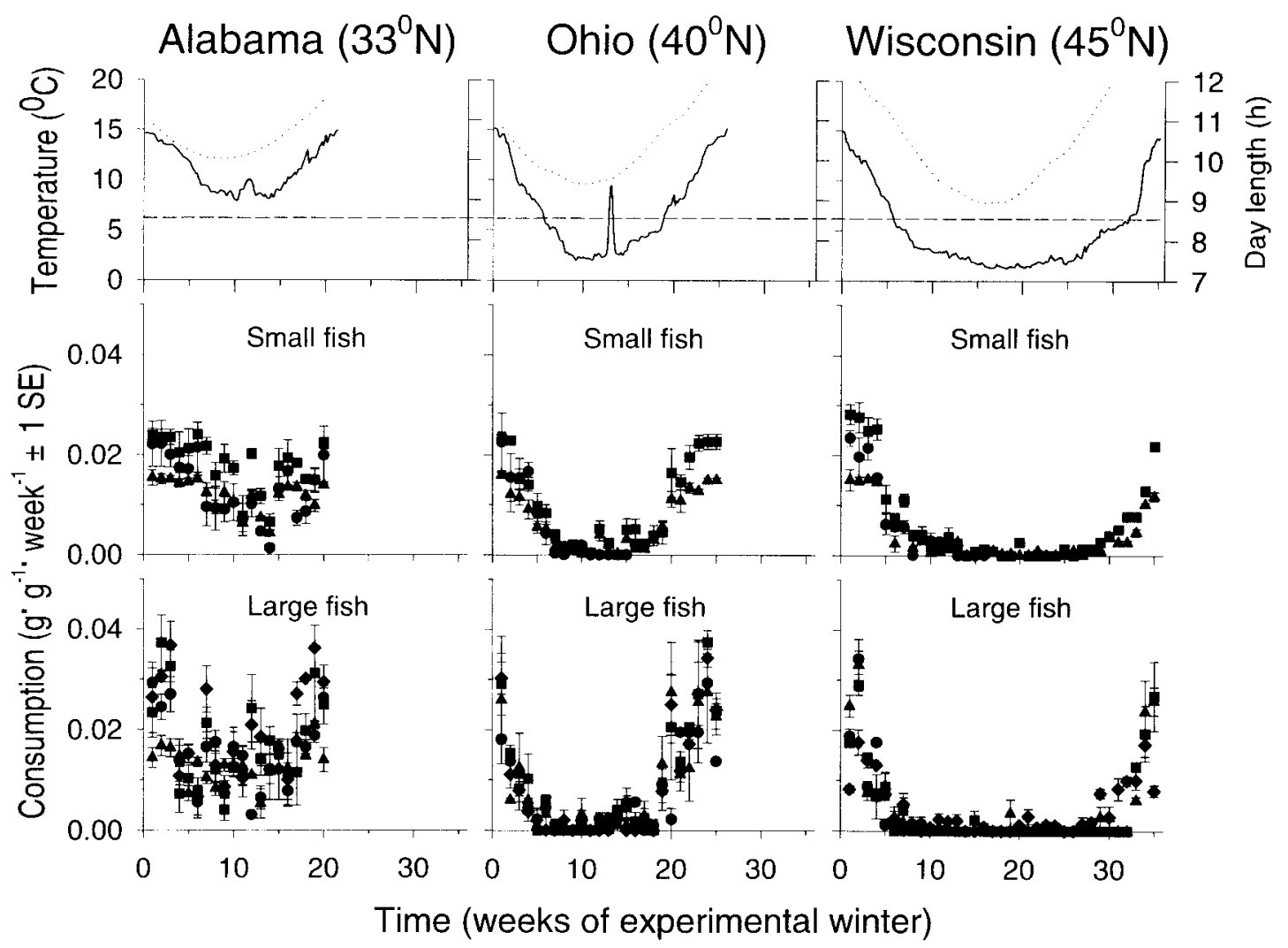

Figure 1.-Temperature and day length regimes (top panels) and mean consumption rates of small (middle panels; $<100 \mathrm{~mm}$ total length) and large (bottom panels; $\geq 100 \mathrm{~mm}$ ) largemouth bass in experimental Alabama winter (left panels), Ohio winter (center panels), and Wisconsin winter (right panels). Day length is plotted as a dotted line and temperature as a solid line in the top row. The temporary peak in temperature during the middle of the Ohio winter was due to equipment failure. $\bullet$ indicates Alabama fish; $\boldsymbol{\|}$ indicates Ohio fish; $\boldsymbol{\Delta}$ indicates Wisconsin fish; and indicates extra-large Ohio fish. The dashed line on the row of top panels indicates the temperature below which feeding was infrequent. Data plotted on each panel extend to the end of each experimental winter.

graphic origin. We also tested whether total survival differed among winters.

\section{Results}

Temperatures were less than $6^{\circ} \mathrm{C}$ on 0,47 , and $73 \%$ of days in the Alabama, Ohio, and Wisconsin winters, respectively, with corresponding minimum temperatures of $7.8,2$, and $1.3^{\circ} \mathrm{C}$ (Figure 1 ). Largemouth bass consumed prey during winter at temperatures that were greater than or equal to $6^{\circ} \mathrm{C}$. At less than $6^{\circ} \mathrm{C}$, feeding continued infrequently. Consumption rates were positively correlated with temperature in each winter (Spearman's rank, Alabama: $r=0.54, P<0.0001$; Ohio: $r=0.83, P$ $<0.0001$; Wisconsin: $r=0.77, P<0.0001$ ), but neither size nor origin appeared to affect patterns (Figure 1).
Size did not affect weekly growth rates in all winters (Table 2; Figure 2); hence, we plot treatment means in Figure 2. Origin did not affect weekly growth rates in Alabama and Ohio winters, but both origin and the origin $\times$ food interaction influenced growth rates in the Wisconsin winter (Table 2; Figure 2). Food increased growth rates in all winters; starved largemouth bass lost more weight than did their fed counterparts (Table 2; Figure 2). Among fed individuals, those in the Alabama and Ohio winters maintained their weights or even gained weight, whereas those in the Wisconsin winter consistently lost weight (Figure 2). The average percent of total change in wet weight overwinter for fed largemouth bass was 3.6 plus or minus $0.3,2.2$ plus or minus 2.2 , and -9.9 plus or minus 1.9 (treatment means, $N=9$ largemouth 
TABLE 2.- Results of three-way ANCOVAs for effect of total length (continuous variable, the covariate), origin (Alabama, Ohio, Wisconsin), and food (presence/absence) on growth rates $\left(\mathrm{g} \cdot \mathrm{g}^{-1} \cdot \mathrm{week}^{-1}\right)$ of largemouth bass during each experimental winter. Only largemouth bass remaining alive at the end of the experiment were used in the analysis. Only significant interactions were included.

\begin{tabular}{lllrr}
\hline \multirow{6}{*}{ Winter } & \multicolumn{4}{c}{$\begin{array}{c}\text { Degrees } \\
\text { of } \\
\text { freedom } \\
\text { (model, }\end{array}$} \\
Alabama & Factor & error) & \multicolumn{1}{c}{$F$} & \multicolumn{1}{c}{$P$} \\
\hline & Model & 4,119 & 95.04 & $<0.001$ \\
& Size & 1,119 & 2.84 & 0.094 \\
Ohio & Origin & 2,119 & 0.48 & 0.622 \\
& Food & 1,119 & 374.74 & $<0.001$ \\
& Model & 4,65 & 9.10 & $<0.001$ \\
& Size & 1,65 & 0.01 & 0.917 \\
& Origin & 2,65 & 0.13 & 0.875 \\
& Food & 1,65 & 35.79 & $<0.001$ \\
& Model & 4,36 & 10.90 & $<0.001$ \\
& Size & 1,36 & 0.22 & 0.646 \\
& Origin & 1,36 & 4.63 & 0.038 \\
& Food & 1,36 & 32.66 & $<0.001$ \\
& Food $\times$ origin & 1,36 & 4.69 & 0.037 \\
\hline
\end{tabular}

bass) in the Alabama, Ohio, and Wisconsin winters, respectively. Among starved largemouth bass, those in the Wisconsin winter lost proportionally less weight on a weekly basis than did individuals in Ohio or Alabama winters (Figure 2). The average total percent of change in wet weight overwinter for starved largemouth bass was -28.3 plus or minus $6.9,-23.0$ plus or minus 4.2 , and -23.0 plus or minus 2.6 (treatment means, $N$ $=9$ largemouth bass) in the Alabama, Ohio, and Wisconsin winters, respectively. Thus, even though fed largemouth bass grew differently among winters, starved fish in all three winters lost similar amounts of total weight, despite the different winter durations.

Patterns of depletion of energy density $(\mathrm{kJ} / \mathrm{g})$ and total energy content $(\mathrm{kJ})$ differed from those of weight loss. Across all winters, the effect of size on changes in energy density and total energy content was significant (Wilk's lambda, $P<0.05$; Table 3), with small individuals depleting more energy than large ones (Figures 3 and 4). In the Alabama winter, results from both the univariate ANOVAs and MANOVA revealed that energy density and total energy content of fed largemouth bass from all latitudes declined less than those of their starved counterparts (Table 3; Figures 3 and 4). Total energy content of fed largemouth bass did not decline during this winter, whereas losses for starved individuals reached $40 \%$ (Figure 4). In

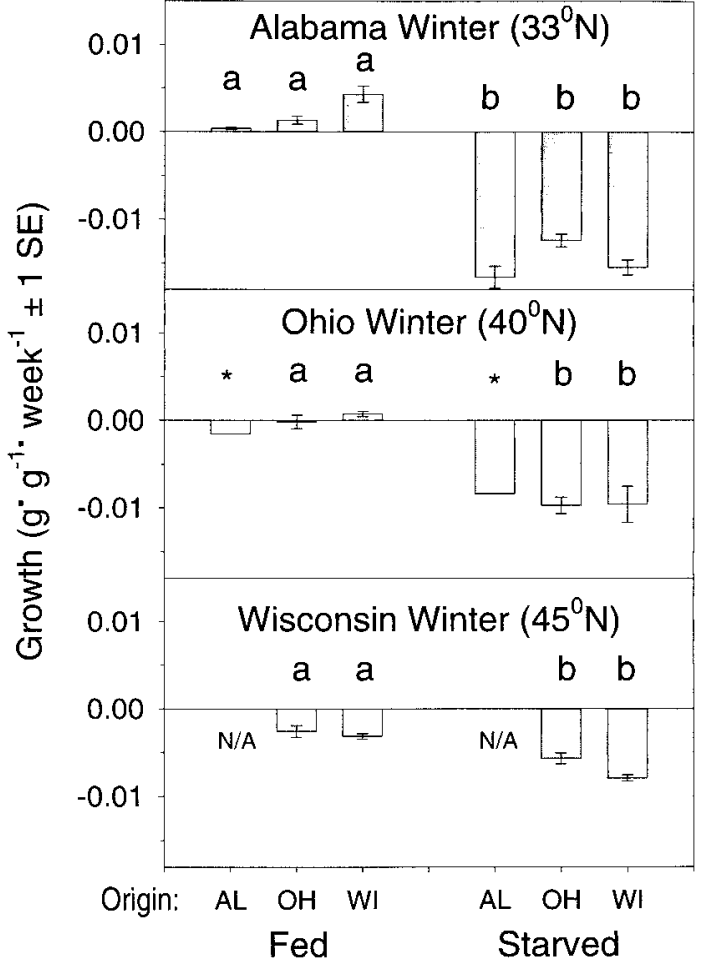

Figure 2.-Mean $\pm 1 \mathrm{SE}$ growth rates of fed and starved largemouth bass in the experimental Alabama winter (top panel), Ohio winter (middle panel), and Wisconsin winter (bottom panel). $\mathrm{AL}, \mathrm{OH}$, and $\mathrm{WI}$ indicate fish of Alabama, Ohio, and Wisconsin origin, respectively. Lowercase $a$ and $b$ indicate significant differences (Scheffes post hoc test within ANCOVA, alpha $=0.05$ ). Only largemouth bass remaining alive at the end of the experiments were used in this analysis. N/A indicates that no data were available (all largemouth bass died). Means with an $*$ indicate treatments in which sample sizes were too small for analysis.

the Ohio winter, most Alabama largemouth bass died, precluding conclusions about their energy depletion. The univariate ANOVA demonstrated that both fed and starved largemouth bass from Ohio and Wisconsin in the Ohio winter lost similar levels (15-30\%) of energy density (food effect, NS; Table 3; Figure 3). However, a significant food effect for proportional change in total energy content suggested that fed and starved largemouth bass lost about 20 and $40 \%$ of total energy content, respectively, in the Ohio winter (Table 3; Figure 4). In the Wisconsin winter, all Alabama largemouth bass died. A significant food*origin effect for change in energy density suggested that starved Ohio largemouth bass lost more energy density than did their fed counterparts in this winter, and 
TABLE 3.-Results of a three-way MANOVA for effect of total length (continuous variable, the covariate), origin (Alabama, Ohio, Wisconsin), and food (presence/absence) on proportional change in energy density and total energy ([final - initial]/initial) of largemouth bass during each experimental winter. Only largemouth bass remaining alive at the end of the experiment were used in the analysis. Only significant interactions were included.

\begin{tabular}{|c|c|c|c|c|c|c|c|c|}
\hline \multirow[b]{2}{*}{ Winter } & \multirow[b]{2}{*}{ Factor } & \multirow{2}{*}{$\begin{array}{c}\text { Degrees of } \\
\text { freedom } \\
\text { (model, } \\
\text { error) }\end{array}$} & \multicolumn{2}{|c|}{ Change in energy density } & \multicolumn{2}{|c|}{ Change in total energy } & \multicolumn{2}{|c|}{ MANOVA Wilk's $\lambda$} \\
\hline & & & $F$ & $P$ & $F$ & $P$ & $F$ & $P$ \\
\hline \multirow[t]{4}{*}{ Alabama } & Model & 6,37 & 14.26 & $<0.001$ & 25.91 & $<0.001$ & & \\
\hline & Size & 1,37 & 6.38 & 0.02 & 11.25 & 0.002 & 5.44 & 0.009 \\
\hline & Origin & 2,37 & 13.51 & $<0.001$ & 6.22 & 0.005 & 7.64 & $<0.001$ \\
\hline & Food & 1,37 & 38.68 & $<0.001$ & 121.81 & $<0.001$ & 63.45 & $<0.001$ \\
\hline \multirow[t]{4}{*}{ Ohio } & Model & 6,33 & 13.10 & $<0.001$ & 8.76 & $<0.001$ & & \\
\hline & Size & 1,33 & 37.89 & $<0.001$ & 6.18 & 0.02 & 20.51 & $<0.001$ \\
\hline & Origin & 2,33 & 20.51 & $<0.001$ & 6.57 & 0.005 & 7.84 & $<0.001$ \\
\hline & Food & 1,33 & 2.82 & 0.10 & 17.04 & $<0.001$ & 9.19 & 0.001 \\
\hline \multirow[t]{5}{*}{ Wisconsin } & Model & 4,33 & 13.58 & $<0.001$ & 7.73 & $<0.001$ & & \\
\hline & Size & 1,33 & 50.41 & $<0.001$ & 21.75 & $<0.001$ & 24.39 & $<0.001$ \\
\hline & Origin & 1,33 & 9.82 & 0.004 & 3.02 & 0.09 & 4.91 & 0.01 \\
\hline & Food & 1,33 & 5.37 & 0.03 & 16.25 & $<0.001$ & 8.05 & 0.002 \\
\hline & Food $*$ Origin & 1,33 & 4.81 & 0.04 & & & & \\
\hline
\end{tabular}

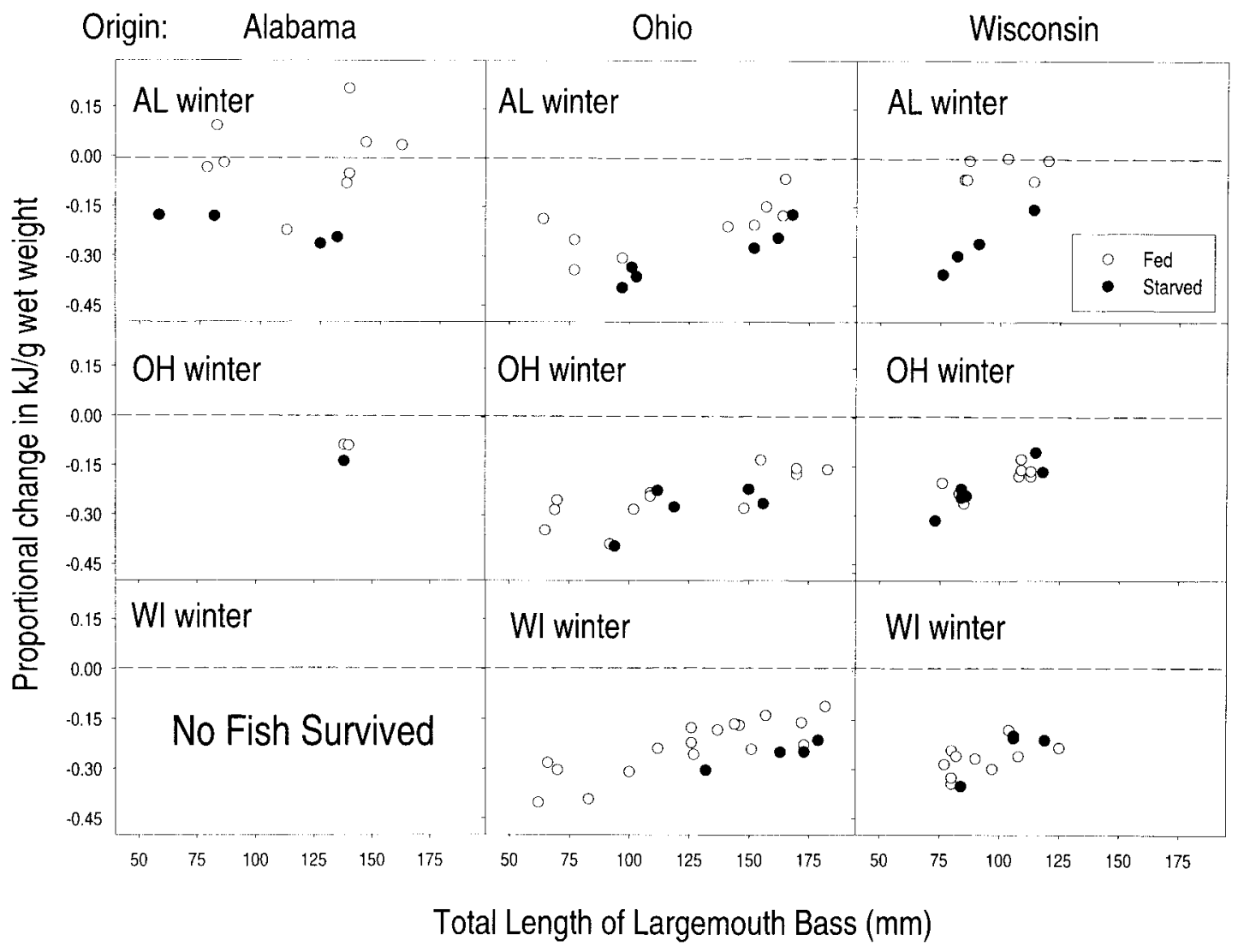

FIgURE 3.-Proportional change in energy density [(final - initial)/initial] of starved $(\bullet)$ and fed $(\bigcirc)$ largemouth bass in the simulated Alabama winter (top row), Ohio winter (middle row), and Wisconsin winter (bottom row). Results for Alabama, Ohio, and Wisconsin largemouth bass are included in the left, middle, and right columns, respectively. The panel for Alabama largemouth bass in the Wisconsin winter is not included because of mortality. The dashed line indicates where energy density did not change during the winter. 


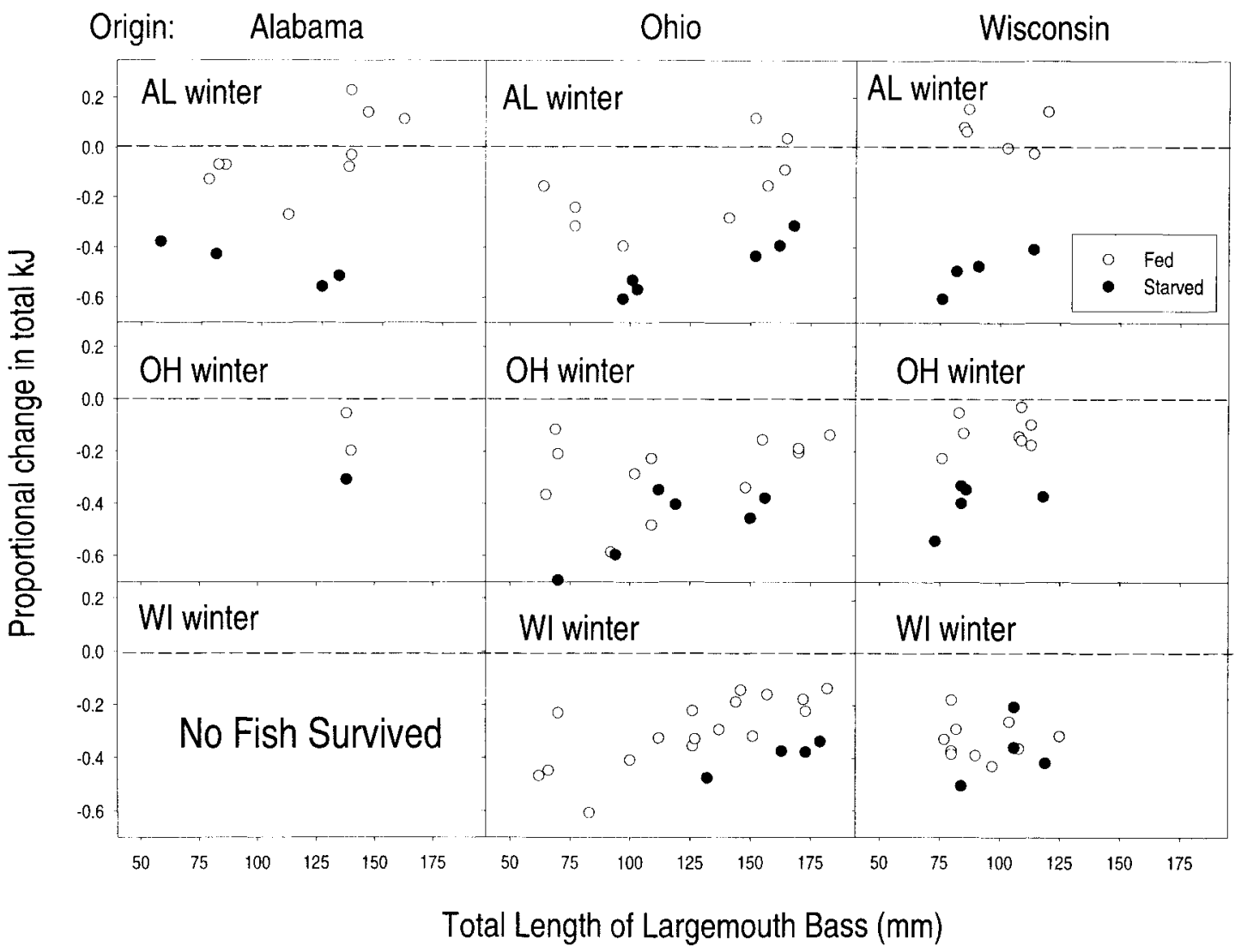

FIGURE 4.-Proportional change in total energy content [(final - initial)/initial] of starved $(\bullet)$ and fed $(\bigcirc)$ largemouth bass in the simulated Alabama winter (top row), Ohio winter (middle row), and Wisconsin winter (bottom row). Results for Alabama, Ohio, and Wisconsin largemouth bass are included in the left, middle, and right columns, respectively. The panel for Alabama largemouth bass in the Wisconsin winter is not included because of mortality. The dashed line indicates where total energy content did not change during the winter.

both fed and starved Wisconsin largemouth bass lost similar levels (Table 3; Figure 3). All fed largemouth bass lost less total energy content (about 30\%) than did their starved counterparts (about 40\%) (food effect, $P<0.05$; Table 3; Figure 4).

Overall survival was highest in the short Alabama winter, lower in the intermediate Ohio winter, and lowest in the long Wisconsin winter ( $\chi^{2}$ test, $P<0.05$; Table 4 ). More fed largemouth bass survived than did their starved counterparts in all winters. Fewer small than large largemouth bass survived in the Alabama and Wisconsin winters. Survival was equivalent between sizes in the Ohio winter (Table 4). Relative to the Alabama winter, fish origin affected survival in the Ohio and Wisconsin winters, because Alabama largemouth bass survived poorly in them (Table 4). Disease may have contributed to mortality, and it had the greatest effect in the warm Alabama winter (Table 4).

\section{Discussion}

Our experiment demonstrated that processes operating at local (i.e., food, size, origin) and geographic (i.e., winter severity) scales interact to influence growth and survival of age-0 largemouth bass. Potential physiological responses that may have contributed to patterns of survival include energy depletion, cold tolerance, and disease susceptibility. Below, we explore how these local and geographic processes influence survival and recruitment via these physiological mechanisms.

\section{Energy Depletion}

During winter, persistent cold temperatures plus reduced daylight may contribute to starvation, exhaustion of energy reserves, and death, either 
TABLE 4.- Percent survival of largemouth bass at the end of each experimental winter as a function of winter, food, size, and origin. Percent of all largemouth bass that died and showed physical signs of disease are included in the bottom row. Results of individual chi-squared tests to determine how each factor affected survival are shown above percentages.

\begin{tabular}{llll}
\hline \multicolumn{1}{c}{ Treatment } & \multicolumn{1}{c}{$\begin{array}{c}\text { Alabama winter } \\
(\%)\end{array}$} & \multicolumn{1}{c}{$\begin{array}{c}\text { Ohio winter } \\
(\%)\end{array}$} & \multicolumn{1}{c}{$\begin{array}{c}\text { Wisconsin winter } \\
(\%)\end{array}$} \\
\hline Overall survival & $\chi^{2}=23.4^{* * *}$ & & \\
& 61.1 & 59.4 & 34.9 \\
Food & $\chi^{2}=12.1^{* *}$ & $\chi^{2}=3.9^{*}$ & $\chi^{2}=11.3^{* *}$ \\
Fed & 76.2 & 70.2 & 49.2 \\
Starved & 46.0 & 51.7 & 20.6 \\
Size & $\chi^{2}=7.2^{*}$ & $\chi^{2}=2.3^{\mathrm{ns}}$ & $\chi^{2}=4.4^{*}$ \\
$\leq 100 \mathrm{~mm}$ & 50.0 & 53.4 & 25.4 \\
$>100 \mathrm{~mm}$ & 73.3 & 67.2 & 43.3 \\
Origin & $\chi^{2}=0.20^{\mathrm{ns}}$ & $\chi^{2}=57.5^{* * *}$ & $\chi^{2}=23.0^{* * *}$ \\
Alabama & 61.1 & 8.3 & 0.0 \\
Ohio & 63.0 & 76.1 & 46.3 \\
$\quad$ Wisconsin & 58.3 & 91.4 & 50.0 \\
Disease & 62.0 & 13.8 & 21.7 \\
\hline
\end{tabular}

*** $P<0.001, * * P<0.01, * P<0.05$.

through (1) direct suppression of consumption or (2) seasonally low food availability. In addition, local variability among systems in terms of food availability may influence patterns of energy depletion and survival.

In our experiment, winter temperature drove much of the variation in consumption by largemouth bass in all winters. Metabolism of largemouth bass, like that of many fishes, declines with declining temperature (Brett and Groves 1979; Rice et al. 1983; Jobling 1993), likely contributing to reduced consumption. Although feeding continued through winter, it was infrequent below $6^{\circ} \mathrm{C}$. Previous investigators have suggested that largemouth bass do not feed below $10^{\circ} \mathrm{C}$ (Markus 1932; Johnson and Charlton 1960). Hence, largemouth bass should be expected to feed and grow more during winter than was previously predicted.

Feeding largemouth bass minimized weight loss during winter. To illustrate, in the Alabama winter, largemouth bass of all sizes fed during the entire winter and gained weight. In the intermediate Ohio winter, fed individuals maintained their original weights, as was expected for individuals that were consuming a maintenance ration. In the long winter (Wisconsin), fed largemouth bass lost weight, which likely was caused by the extended time spent at temperatures below which feeding was quite infrequent. Because wet weight changes were consistent among all sizes of largemouth bass of Alabama, Ohio, and Wisconsin origins, overwinter food availability and temperature should influence wet weight similarly throughout the range of this species.
Although the relationship among consumption, wet-weight change, and winter severity was interpretable for fed largemouth bass, some individuals in the Alabama and Ohio winters lost up to $40 \%$ of their initial energy density, even when wet weight and total energy content increased or did not change. As expected, small largemouth bass that were fed lost proportionately more energy density than did their large counterparts, though relationships were quite variable. For largemouth bass that increased or maintained body weight and total energy content while losing energy density, proximate composition likely changed, perhaps because the relative proportion of protein increased while that of lipids declined (Weatherley and Gill 1987). In another experiment, fed age-0 largemouth bass in outdoor pools gained wet weight while energy density declined during winter; counterparts reared during the same time in 0.4-ha hatchery ponds maintained wet weight and energy density (Garvey et al. 1998). Differences in prey availability and proximate composition between pools and ponds may have influenced energy allocation decisions and patterns of largemouth bass growth in this experiment (Garvey et al. 1998). Because all largemouth bass consumed similar quantities of prey under identical conditions in our experiment, energy allocation decisions likely differed among individuals. Perhaps these decisions were related to adaptations to local environmental conditions, although their potential value to survival is unknown.

Food improved the growth of fed individuals, although its importance declined with increasing 
latitude. For starved individuals, wet weight, energy density, and total energy content declined during all winters, with these negative effects being more severe for small individuals. Because weekly weight loss of starved largemouth bass declined with increasing latitude, absolute weight loss was similar (about 25\%) for all sizes of largemouth bass in all three winters. Overall loss of energy density also was similar among winters. These results contradict the expectation that fish in long, cold winters will lose more weight and energy reserves than will fish in warm, short winters when food is scarce (Post and Evans 1989; Schultz and Conover 1997). In high-latitude winters, a warmwater fish like largemouth bass may reduce energetic costs by lowering its metabolic rate and by then persisting in a state of torpor when temperatures remain below a threshold temperature for some set period of time (e.g., in northern winters) (Evans 1984; Sullivan 1986; Wright et al. 1999). At low latitudes, winter temperatures typically may rise above the threshold temperature required to induce torpor, thus precluding its occurrence. The greater weekly weight loss of starved largemouth bass in the Alabama winter relative to the Wisconsin winter supports this hypothesis.

Our results indicate that increasing winter severity increases energy depletion of largemouth bass by suppressing consumption. If food production declines during winter, as it certainly does at high latitudes, reduced prey should also contribute to energy loss. Among-system variation in prey availability at a given latitude should also influence patterns of energy depletion. Will these multiple scale patterns of energy depletion translate to survival patterns? Loss of lipid reserves, which correlates well with energy density depletion, often has been implicated as a major cause of overwinter mortality (Miranda and Hubbard 1994a; Ludsin and DeVries 1997). In our experiment, more fed fish survived than did starved fish, and size improved survival in the Alabama and Wisconsin winters. Hence, energy depletion in concert with other size-related factors likely mediates winter survival and recruitment to later life stages. Overall survival of a cohort of age-0 largemouth bass should decline with increasing latitude (Shuter et al. 1980; Shuter and Post 1990). However, within each winter, increased food availability should greatly facilitate survival of age-0 largemouth bass. We agree with Adams et al. (1982) that direct effects of winter on prey production and availability will influence growth, survival, and year-class strength.

\section{Other Mechanisms}

In addition to energy depletion, other factors that vary across local and latitudinal scales might influence survival. Largemouth bass origin affected survival across winters. More Alabama largemouth bass died than did largemouth bass from other origins in the Ohio and Wisconsin winters. Often, these largemouth bass lost equilibrium before dying, which suggests that osmoregulatory failure rather than energy depletion caused the mortality. Perhaps Alabama largemouth bass differed physiologically in their tolerance to cold temperatures (which declined to $2-3^{\circ} \mathrm{C}$ ) or to the rapidity of cooling. To illustrate, when first acclimated to warm temperatures $\left(21^{\circ} \mathrm{C}\right)$ and then immediately immersed in cold water, the Florida subspecies suffered higher mortality than did the northern subspecies at temperatures $\left(<8.5^{\circ} \mathrm{C}\right)$ much higher than those used in our experiments (Cichra et al. 1982). In contrast, Florida and northern largemouth bass cooled, at $1^{\circ} \mathrm{C} / \mathrm{d}$, to $3^{\circ} \mathrm{C}$ over a period of $21 \mathrm{~d}$ suffered no differential mortality (Philipp 1992). Because of extensive stocking of the Florida subspecies, Alabama largemouth bass contained about $96 \%$ of the Florida genome through hybridization (M. Maceina, Auburn University, Department of Fisheries and Allied Aquacultures, personal communication). High mortality of Alabama largemouth bass in the Ohio and Wisconsin winters likely occurred as a result of their intolerance to cold temperatures, even given our slower cooling rates (about $0.5^{\circ} \mathrm{C} / \mathrm{d}$ ) as compared with those of Philipp (1992).

It is important to note that we did not control for environmentally driven developmental effects by hatching and rearing all largemouth bass under similar conditions (see Isely et al. 1987). Further, we know little about the genetic history of the largemouth bass from Ohio and Wisconsin, although these stocks are likely genetically distinct from the Florida subspecies (Philipp et al. 1983). Though differences in tolerance to cold temperatures may have been driven by genetic differences, maternal effects or early environmental conditions may have contributed to observed patterns.

Disease may be an important factor influencing recruitment of fishes, especially during winter (Adams et al. 1982). Although we originally expected that size-selective winter mortality would increase with increasing latitude, more small large- 
mouth bass died than did their large counterparts in the longest (Wisconsin) and shortest (Alabama) winters only. In the intermediate winter, mortality was equivalent between the small and large age0 largemouth bass. Interestingly, the prevalence of disease-related deaths was lowest in the Ohio winter, in which size-dependent mortality did not occur. Perhaps size-related susceptibility to disease in concert with energy depletion contributed to patterns of mortality.

The availability of cover also may influence age0 fish survival during winter (Miranda and Hubbard 1994b; Quinn and Peterson 1996). Cover may provide shelter from predators, thus reducing predatory mortality (Miranda and Hubbard 1994b; Garvey et al. 1998). In addition, shelters may reduce activity levels (see Wright et al. 1999), potentially reducing energy depletion during winter. Because we did not provide shelters in our experiment, largemouth bass may have been more active and may have depleted more energy than would be expected in systems in which refuge is abundant.

\section{Conclusions and Management Implications}

Size is often implicated as an important predictor of winter survival and, thus, of recruitment success. From an evolutionary perspective, winter may be an important selective force at high latitudes, where selection for rapid summer growth of age-0 fish should occur to compensate for short first growing seasons (Conover 1990; Conover and Present 1990). In our experiment, increasing size was positively related to survival in the low- and high-latitude winters and negatively related to energy depletion in all winters. Thus, our results indicate that large size increases the probability of winter survival throughout the range of largemouth bass. Selection for rapid summer growth to enhance winter body size should not be exclusive to high latitudes, unless large size or rapid growth rates reduce summer survival. In addition to energy depletion, other factors, such as food availability, disease, cold tolerance (this study), and predation (Green 1982; Miranda and Hubbard 1994b; Garvey et al. 1998), may intensify or ameliorate the potentially negative effect of small size on overwinter survival.

Both local and latitudinal differences in overwinter food availability likely do influence growth and survival of age-0 largemouth bass. Managers may predict that high forage availability during fall through winter translates to improved growth, survival, and recruitment. Because largemouth bass appear to compensate for the costs of pro- longed cold temperatures at northern latitudes by reducing metabolic costs (Wright et al. 1999; also see Kershner 1998 for a similar mechanism in walleye Stizostedion vitreum), managers of northern lakes should still expect only moderate weight loss of individuals that are consuming prey during winter. Increasing winter duration with increasing latitude may well set the northern limit for largemouth bass, as it likely does for smallmouth bass Micropterus dolomieu (Shuter et al. 1980).

Our experiments lend insight into the debate about stocking the Florida subspecies of largemouth bass outside of its native range, a practice which is employed because this subspecies grows faster and reaches greater maximum size than does the northern subspecies (Maceina and Murphy 1992). Stocking these individuals and creating hybrids in systems with long, cold winters may lead to reduced survival, which may eventually degrade the natural populations (Philipp 1992). One reason such degradation may occur is that largemouth bass from southern systems are "confronted with an energy deficit during lengthy northern winters, because they fail to alter their metabolic strategy from one of maximizing somatic growth to one of shunting energy to storage reserves" (Philipp 1992). Our experiments suggest that patterns of growth and energy depletion generally were similar among largemouth bass from the three origins and that physiological differences in cold tolerance likely were responsible for the poor survival of Alabama largemouth bass. Regardless of the causal mechanism, we agree with Philipp (1992) that the practice of stocking largemouth bass outside of their native range may be deleterious because of the potentially negative effects of outbreeding depression.

By placing our research in a latitudinal context, we have learned that the mechanisms influencing recruitment of largemouth bass and other widely distributed species (e.g., Leggett and Frank 1997) should vary as a function of important local and geographic factors. Managers must consider these interacting processes when they are predicting recruitment within their local populations. Although fish are often physiologically plastic, constraints created by local adaptation may curb the stocking success of some species and may potentially degrade native stocks. When possible, research should encompass important ecological processes operating at the scale of a species's range. With this approach, we garner important insight into the implications of management strategies that may be missed at smaller scales of inquiry. 


\section{Acknowledgments}

We thank Kristen Ferry, Bridey Thompson, Tom Stahl, Heather McCann, Mike McKee, and Rick Ginsberg for their outstanding efforts. Jim Breck and three anonymous reviewers provided comments that substantially improved the manuscript. This research was funded by National Science Foundation grant DEB 9407859 and associated Research Experiences for Undergraduates supplement to A. H. Fullerton and by Federal Aid in Sport Fish Restoration project F-69-P, administered jointly by the U.S. Fish and Wildlife Service and the Ohio Division of Wildlife. A Presidential Fellowship from The Ohio State University supported J. E. Garvey.

\section{References}

Adams, S. M., and D. L. DeAngelis. 1987. Indirect effects of early bass-shad interactions on predator population structure and food web dynamics. Pages 103-117 in W. C. Kerfoot and A. Sih, editors. Predation: direct and indirect impacts on aquatic communities. University Press of New England, Hanover, New Hampshire.

Adams, S. M., R. B. McLean, and M. M. Huffman. 1982. Structuring of a predator population through temperature-mediated effects on prey availability. $\mathrm{Ca}$ nadian Journal of Fisheries and Aquatic Sciences 39:1175-1184.

Bennett, W. A., R. J. Currie, P. F. Wagner, and T. L. Beitinger. 1997. Cold tolerance and potential overwintering of the red-bellied piranha Pygocentrus nattereri in the United States. Transactions of the American Fisheries Society 126:841-849.

Brett, J. R., and T. D. D. Groves. 1979. Physiological energetics. Pages 279-352 in W. S. Hoar, D. J. Randall, and J. R. Brett, editors. Fish physiology. Academic Press, New York.

Brown, M. L., and B. R. Murphy. 1994. Length-structured evaluation of seasonal energy patterns in largemouth bass. Journal of Freshwater Ecology 9: 281-288.

Cargnelli, L. M., and M. R. Gross. 1996. The temporal dimension in fish recruitment: birth date, body size, and size-dependent survival in a sunfish (bluegill: Lepomis macrochirus). Canadian Journal of Fisheries and Aquatic Sciences 53:360-367.

Cargnelli, L. M., and M. R. Gross. 1997. Fish energetics: larger individuals emerge from winter in better condition. Transactions of the American Fisheries Society 126:153-156.

Cichra, C. E., W. H. Neill, and R. L. Noble. 1982. Differential resistance of the northern and Florida largemouth bass to cold shock. Proceedings of the Annual Conference Southeastern Association of Fish and Wildlife Agencies 34(1980):19-24.

Conover, D. O. 1990. The relation between capacity for growth and length of growing season: evidence for and implications of countergradient variation.
Transactions of the American Fisheries Society 119: 416-430.

Conover, D. O., and T. M. C. Present. 1990. Countergradient variation in growth rate: compensation for length of the growing season among Atlantic silversides from different latitudes. Oecologia 83: 316-324.

Coutant, C. C. 1975. Responses of bass to natural and artificial temperature regimes. Pages $272-285$ in $\mathrm{H}$. Clepper, editor. Black bass biology and management. Sportfishing Institute, Washington, D.C.

Crawshaw, L. I. 1984. Low temperature dormancy in fish. American Journal of Physiology 246:479486.

Evans, D. O. 1984. Temperature independence of the annual cycle of standard metabolism in the pumpkinseed. Transactions of the American Fisheries Society 113:494-512.

Garvey, J. E., R. A. Wright, and R. A. Stein. 1998. Overwinter growth and survival of age-0 largemouth bass: revisiting the role of body size. Canadian Journal of Fisheries and Aquatic Sciences 55:2414-2424.

Gelwick, F. P., E. R. Gilliand, and W. J. Matthews. 1995. Introgression of the Florida largemouth bass genome into stream populations of northern largemouth bass in Oklahoma. Transactions of the American Fisheries Society 124:550-562.

Green, D. M. 1982. Population dynamics of largemouth bass (Micropterus salmoides) and chain pickerel (Esox niger) in Dryden Lake, New York. Doctoral dissertation. Cornell University, Ithaca, New York.

Griffiths, D., and R. C. Kirkwood. 1995. Seasonal variation in growth, mortality and fat stores of roach and perch in Lough Neagh, Northern Ireland. Journal of Fish Biology 47:537-554.

Gutreuter, S. J., and R. O. Anderson. 1985. Importance of body size to the recruitment process in largemouth bass. Transactions of the American Fisheries Society 114:317-327.

Hall, T. J. 1996. 1995 Ohio B.A.S.S. chapter federation tournament summary. Ohio Division of Wildlife Report, State Project F1DR17, Columbus

Hewett, S. W., and B. L. Johnson. 1992. Fish bioenergetics model 2, an upgrade of a generalized bioenergetics model of fish growth for microcomputers. University of Wisconsin Sea Grant Institute, Madison.

Isely, J. J., R. L. Noble, J. B. Koppelman, and D. P. Philipp. 1987. Spawning period and first-year growth of northern, Florida, and intergrade stocks of largemouth bass. Transactions of the American Fisheries Society 116:757-762.

Jobling, M. 1993. Bioenergetics: feed intake and energy partitioning. Pages 1-44 in J. C. Rankin and F. B. Jensen, editors. Fish ecophysiology. Chapman and Hall, London.

Johnson, M. G., and W. H. Charlton. 1960. Some effects of temperature on the metabolism and activity of the largemouth bass, Micropterus salmoides Lacepede. Progressive Fish-Culturist 22:155-163. 
Kershner, M. W. 1998. Walleye predatory demand and prey supply in Lake Erie: exploring environmental variation and its historical effects. Doctoral dissertation. Ohio State University, Columbus.

Leggett, W. C., and K. T. Frank. 1997. A comparative analysis of recruitment variability in North Atlantic flatfishes-testing the species range hypothesis. Journal of Sea Research 37:281-299.

Ludsin, S. A. 1994. Understanding first-year survival of a freshwater piscivore: the inter-dependency of life-history stages. Master's thesis. Auburn University, Auburn, Alabama.

Ludsin, S. A., and D. R. DeVries. 1997. First-year recruitment of largemouth bass: the inter-dependency of early life stages. Ecological Applications 7: $1024-1038$.

Lyons, J. 1997. Influence of winter starvation on the distribution of smallmouth bass among Wisconsin streams: a bioenergetics modeling assessment. Transactions of the American Fisheries Society 126: 157-162.

Maceina, M. J., and B. R. Murphy. 1992. Stocking largemouth bass outside its native range. Transactions of the American Fisheries Society 121:686-690.

Markus, H. C. 1932. The extent to which temperature changes influence food consumption in largemouth bass (Huro floridana). Transactions of the American Fisheries Society 62:202-210.

Meyer, K. A., and J. S. Griffith. 1997. First-winter survival of rainbow trout and brook trout in the Henrys Fork of the Snake River, Idaho. Canadian Journal of Zoology 75:59-63.

Miranda, L. E., and W. D. Hubbard. 1994a. Lengthdependent winter survival and lipid composition of age-0 largemouth bass in Bay Springs Reservoir, Mississippi. Transactions of the American Fisheries Society 123:80-87.

Miranda, L. E., and W. D. Hubbard. 1994b. Winter survival of age-0 largemouth bass relative to size, predators and shelter. North American Journal of Fisheries Management 14:790-796.

Oliver, J. D., G. F. Holeton, and K. E. Chua. 1979. Overwinter mortality of fingerling smallmouth bass in relation to size, relative energy stores and environmental temperature. Transactions of the American Fisheries Society 108:130-136.

Philipp, D. P. 1992. Stocking largemouth bass outside its native range. Transactions of the American Fisheries Society 121:688-691.

Philipp, D. P., W. F. Childers, and G. S. Whitt. 1983. A biochemical genetic evaluation of the northern and Florida subspecies of largemouth bass. Transactions of the American Fisheries Society 112:1-20.

Post, J. R., and D. O. Evans. 1989. Size-dependent overwinter mortality of young-of-the-year yellow perch
(Perca flavescens): laboratory, in situ enclosure, and field experiments. Canadian Journal of Fisheries and Aquatic Sciences 46:1958-1968.

Quinn, T. P., and N. P. Peterson. 1996. The influence of habitat complexity and fish size on overwinter survival and growth of individually marked juvenile coho salmon (Onchorhynchus kisutch) in Big Beef Creek, Washington. Canadian Journal of Fisheries and Aquatic Sciences 53:1555-1564.

Rand, P. S., B. F. Lantry, R. O'Gorman, R. W. Owens, and D. J. Stewart. 1994. Energy density and size of pelagic prey fishes in Lake Ontario, 19781990: implications for salmonine energetics. Transactions of the American Fisheries Society 123:519-534.

Rice, J. A., J. E. Breck, S. M. Bartel, and J. F. Kitchell. 1983. Evaluating the constraints of temperature, activity and consumption on growth of largemouth bass. Environmental Biology of Fishes 9: 263-275.

Schultz, E. T., and D. O. Conover. 1997. Latitudinal differences in somatic energy storage: adaptive responses to seasonality in an estuarine fish (Atherinidae: Menidia menidia). Oecologia 109:516529.

Shuter, B. J., J. A. MacLean, F. E. J. Fry, and H. A. Regier. 1980. Stochastic simulation of temperature effects on first-year survival of smallmouth bass. Transactions of the American Fisheries Society 109: 1-34.

Shuter, B. J., and J. R. Post. 1990. Climate, population viability, and zoogeography of temperate fishes. Transactions of the American Fisheries Society 119: 314-336.

Smith, R. W., and J. S. Griffith. 1994. Survival of rainbow trout during their first winter in the Henrys Fork of the Snake River, Idaho. Transactions of the American Fisheries Society 123:747-756.

Sullivan, K. M. 1986. Physiology of feeding and starvation tolerance in overwintering freshwater fishes. Pages 259-268 in Proceedings of gutshop '84. W. Junk Publishers, Pacific Grove, California.

Toneys, M. L., and D. W. Coble. 1979. Size-related, first winter mortality of freshwater fishes. Transactions of the American Fisheries Society 108:415-419.

Weatherley, A. H., and H. S. Gill. 1987. The biology of fish growth. Academic Press, New York.

Whitmore, D. H., and C. M. Craft. 1996. Mitochondrial DNA cytochrome $b$ gene variation reveals different largemouth bass genealogies. Journal of Fish Biology 48:695-705.

Wright, R. A., J. E. Garvey, A. H. Fullerton, and R. A. Stein. 1999. Using bioenergetics to explore how winter conditions affect consumption and growth of age-0 largemouth bass. Transactions of the American Fisheries Society 128:603-612. 